\title{
The Effect of Regional Financial Independence, Regional Financial Efficiency and Effectiveness of Regional Original Income on Capital Expenditure (Study in the Provincial Level Regional Government in Indonesia 2013-2017)
}

\author{
Mutiah \\ Universitas Mercubuana
}

\begin{abstract}
This research is analyzed the Influence of Regional Financial Independence, Regional Financial Efficiency and Effectiveness of Regional Original Income (PAD) on Capital Expenditures in Indonesia. Data from this research are secondary data, about regional financial ratios from 33 provinces throughout Indonesia, obtained from the website www.bps.go.id and www.djpk.depkeu.go.id, from 2013-2017. Analysis tool is used multiple regression. The results of this research is found that Regional Financial Independence had a negative and significant effect on Capital Expenditures, while Regional Financial Efficiency did not affect Capital Expenditures and Effectiveness of Regional Original Income (PAD) did not affect Capital Expenditures.

Keywords: Regional Financial Independence, Regional Financial Efficiency, Effectiveness of Regional Original Income (PAD), Capital Expenditures

DOI: $10.7176 / \mathrm{EJBM} / 11-24-05$

Publication date: August $31^{\text {st }} 2019$

\section{INTRODUCTION}

The economic and political crisis that occurred in Indonesia in 1997 has destroyed almost all the economic and political aspects that have affected for a long time. Furthermore, the economic and political crisis which has become a multi-crisis, has resulted in the lower level of capability and capacity of the State in guaranteeing sustainable development. With the implementation of regional autonomy, it does not automatically eliminate the duties, roles and responsibilities of the central government, because the autonomy carried out is not unlimited autonomy. In the framework of autonomy the central government conducts regional development, manages and mobilizes all potentials of an area utilized in an integrated manner to realize people's welfare. Every local government has the obligation to improve public services, accelerate the development of development, and quality and sustainable regional economic growth requires the support of local government investment through additional capital expenditures throughout the Regency, city and province.

In the National Medium Term Development Plan (RPJMN) for 2015-2019 the Government set a proportion of capital expenditure of around $30 \%-35$, but this capital expenditure target was not met. Data on the realization of capital expenditure and regional expenditure are shown in table 1. As follows:
\end{abstract}

Table 1.

Spending realization ratio $2012-2016$

(Thousand IDR)

\begin{tabular}{|c|c|c|c|c|c|}
\hline \multirow{2}{*}{ Year } & Regional spending & \multicolumn{2}{|c|}{$\begin{array}{c}\text { Direct, HR, Service Goods } \\
\text { spending }\end{array}$} & \multicolumn{2}{c|}{ Spending Capital } \\
\cline { 2 - 6 } & Total $(\mathrm{Rp})$ & Total $(\mathrm{Rp})$ & $\%$ & Total $(\mathrm{Rp})$ & $\%$ \\
\hline 2012 & $611.686 .030 .535,32$ & $483.618 .241 .749,10$ & 79,06 & $128.067 .788 .786,22$ & 20,94 \\
\hline 2013 & $707.010 .145 .548,57$ & $548.050 .864 .155,73$ & 77,52 & $158.959 .281 .392,84$ & 22,48 \\
\hline 2014 & $789.794 .845 .499,04$ & $612.924 .760 .515,46$ & 77,61 & $176.870 .084 .983,58$ & 22,39 \\
\hline 2015 & $906.926 .892 .458,75$ & $701.094 .179 .689,25$ & 77,30 & $205.832 .712 .769,50$ & 22,70 \\
\hline 2016 & $1.000 .779 .537 .737,73$ & $780.087 .978 .162,88$ & 77,95 & 220.691 .559 .574 .87 & 22,05 \\
\hline Total & $4.016 .197 .451 .779,40$ & $3.125 .776 .024 .272,41$ & & $890.421 .427 .507,00$ & \\
\hline
\end{tabular}

Source: DJPK

The success of regional autonomy can be seen from the regional financial performance. Regional financial performance can be calculated using regional financial ratios which can be seen from: regional financial independence ratio, effectiveness ratio and regional financial efficiency ratio (Ardhini, 2011: 2).

Regional financial independence is the ability of local governments to finance their own government activities, development and services to communities that have paid taxes and levies as a source of income needed by the regions. Problems that occur that in the implementation of regional financial independence there are inequalities and gaps in resources and the potential possessed between one region and another 
Table 2.

Independency Level for Regional Finance 2016

(Thousand rupiah)

\begin{tabular}{|c|c|c|c|c|}
\hline \multirow{2}{*}{ Year } & Revenue & PAD Relation & \multirow{2}{*}{ Level } \\
\cline { 2 - 4 } & Total $(\mathrm{Rp})$ & total $(\mathrm{Rp})$ & $\%$ & \\
\hline 2012 & $638.489 .916,852,54$ & $131.481 .938 .245,56$ & 20,59 & moderate \\
\hline 2013 & $719.391 .554 .271,49$ & $157.643 .643 .146,82$ & 21,91 & moderate \\
\hline 2014 & $826.136 .021 .630,66$ & $200.504 .643 .215,34$ & 24,21 & moderate \\
\hline 2015 & $897.048 .525 .834,79$ & $215.376 .545 .577,69$ & 23,92 & moderate \\
\hline 2016 & $1011.166 .346 .275,12$ & $229.400 .595 .245,80$ & 22,64 & moderate \\
\hline Total & $4.092 .232 .364 .864,59$ & $934.407 .365 .431,21$ & & \\
\hline
\end{tabular}

Source: DJPK

In the table above shows that the level of regional financial independence tends to be stable at a moderate level. The regional financial efficiency ratio can be measured by comparing total real expenditure with total regional income. An area is said to be efficient if the regional expenditure is small and the total income is large.

Table 3.

Level of efficiency Regional finance 2012 - 2016

(Thousand Rupiah)

\begin{tabular}{|c|c|c|c|c|}
\hline \multirow{2}{*}{ Year } & Revenue & \multicolumn{2}{|c|}{ Regional Spending } & \multirow{2}{*}{ Efficiency } \\
\cline { 2 - 4 } & Total $(\mathrm{Rp})$ & Total $(\mathrm{Rp})$ & \multicolumn{1}{c|}{$\%$} & Low \\
\hline 2012 & $638.489 .916,852,54$ & $611.686 .030 .535,32$ & 95,80 & Low \\
\hline 2013 & $719.391 .554 .271,49$ & $707.010 .145 .548,57$ & 98,28 & Low \\
\hline 2014 & $826.136 .021 .630,66$ & $789.794 .845 .499,04$ & 95,60 & Not efficiency \\
\hline 2015 & $897.048 .525 .834,79$ & $906.926 .892 .458,75$ & 101,10 & Low \\
\hline Total & $1011.166 .346 .275,12$ & $1.000 .779 .537 .737,73$ & 98,97 & \\
\hline
\end{tabular}

Source: DJPK

The data above shows fluctuating presentation figures, does not have a positive trend. The regional financial effectiveness ratio, this ratio aims to measure the ability of regional governments to realize the budgeted PAD.

Table 4.

Realization effectively level for PAD 2012 - 2016 (Thousand rupiah)

\begin{tabular}{|c|c|c|c|c|}
\hline \multirow{3}{*}{ Year } & \multirow{2}{*}{\multicolumn{3}{|c|}{ Realization }} & \multirow{3}{*}{ Efectivity level } \\
\hline & & & & \\
\hline & Total (Rp) & Total (Rp) & $\%$ & \\
\hline 2012 & $112.421 .510 .671,68$ & $131.481 .938 .245,56$ & 116,95 & Very \\
\hline 2013 & $140.035 .753 .766,40$ & $157.643 .643 .146,82$ & 112,57 & Very \\
\hline 2014 & $180.675 .153 .515,58$ & $200.504 .643 .215,34$ & 110,98 & Very \\
\hline 2015 & $215.088 .368 .978,46$ & $215.376 .545 .577,69$ & 100,13 & Very \\
\hline 2016 & $229.399 .260 .788,22$ & $229.400 .595 .245,80$ & 100,00 & Very \\
\hline Total & $877.620 .047 .720,35$ & $934.407 .365 .431,21$ & & \\
\hline
\end{tabular}

Sources: DJPK

The data above shows the level of realization of PAD is very effective, but the percentage from year to year (2012-2016) tends to decrease. Based on the description above, the authors are interested in researching with the title, "The Effect of Regional Financial Independence, Regional Financial Efficiency and Effectiveness of Regional Original Income on Capital Expenditures."

\section{LITERATURE REVIEW}

\section{Capital Expenditures}

According to Halim (2013) capital expenditure is budget expenditure for the acquisition of fixed assets and other assets that provide benefits for more than one accounting period. Capital expenditure consists of; (1) land expenditure; (2) shopping for equipment and machinery; (3) shopping for buildings and buildings; (4) road, irrigation and network shopping; (5) other fixed assets expenditure; and (6) other asset expenditure. Capital expenditure is a type of regional expenditure classification. Based on Government Accounting Standards Statement No. 02 (PSAP 02), expenditure constitutes all expenditure expenses from the State / State / Regional General Cash Account which reduces the equity of equity funds smoothly in the period of the relevant budget year period which will not be obtained and the payment is returned by the government. Whereas the classification of regional expenditure itself consists of: 
Regional Financial Performance

Regional financial management cannot be separated from the existence of Law Number 17 Year 2003 concerning State Finance, Law Number 1 Year 2004 concerning State Treasury and Law Number 15 Year 2004 concerning Examination of Management and Responsibility of State Finance. With the issuance of Law No. 32 of 2004 and Law No. 33 of 2004, the various basic principles contained in the State Finance Act, the State Treasury Law and the Management Examination Act and the State Financial Responsibility are reaffirmed and become reference in the transfer of regional finance.

Permendagri No. 13 of 2006 states that "performance is the output / outcome of activities / programs that will or has been achieved in connection with the use of the budget with measurable quantity and quality". Local government financial performance is the level of achievement of a work result in the area of regional finance which includes regional revenues and expenditures using financial indicators determined through a policy or statutory provisions during a budget period.

Regional Financial Independence

As stated in Law No. 32 of 2004 that the independence of regional finance means that the government can carry out financing and financial accountability on its own, implementing itself, in the framework of the principle of decentralization. The granting of autonomy to the regions is intended to accelerate the realization of prosperity through regional autonomy by regulating and managing their own government affairs based on the principle of autonomy which is expected to be carried out with regional autonomy, all regions in carrying out regional affairs both governmental and developmental matters each is local revenue (PAD).

Financial independence is calculated based on the comparison between the amount of PAD (Regional Original Income) and total regional income. This ratio shows the degree of PAD contribution to total regional income. The higher the contribution of PAD, the higher the capacity of local governments in implementing decentralization (Mahmudi, 2016). Then this indicator can be formulated as follows:

$K K D=\frac{\text { regional real revenue }}{\text { regional revenue }} \times 100 \%$

Regional Financial Efficiency

Efficiency is the achievement of maximum output with certain inputs or the use of the lowest input to achieve a certain output. Regional Financial Efficiency Ratio (REKD) illustrates the comparison between the amount of costs incurred to obtain income and the realization of income received. Whereas according to Putu Gede (2016), efficiency ratio is a ratio that describes the comparison between output and input or realization of expenditure with realization of regional revenues. The smaller the ratio, the more efficient, and vice versa. The formula for calculating the Financial Efficiency Ratio is as follows:

$$
E K D=\frac{\text { regional spending realization }}{\text { regional revenue }} \times 100 \%
$$

Effectiveness of Local Revenue

The effectiveness of local revenue (PAD) shows the ability of local governments to mobilize revenue From PAD according to the target (Mahmudi 2010: 143). The PAD effectiveness ratio is calculated by comparing the realization of PAD revenue with the target of PAD revenues or budgeted or targeted in the previous APBD. The PAD effectiveness ratio formula is as follows:

$$
E P A D=\frac{\text { revenue realization } \mathrm{PAD}}{\text { Budget } \mathrm{PAD}} \times 100 \%
$$

Based on the equation above it can be stated that the greater the realization of PAD towards the target of PAD revenue, the greater the ratio of regional financial effectiveness or vice versa. The higher the effectiveness ratio of regional finance, the regions have used the Regional Budget effectively.

\section{Previous research}

Vella Kurniasih (2014), conducted a study on the Role of Regional Financial Ratios, Regional Original Revenues (PAD), and General Allocation Funds (DAU) on the Allocation of Capital Expenditures. Conclusions In this study indicate that Regional Original Income (PAD) has a significant influence on the Allocation of Capital Expenditures while the Regional Financial Independence Ratios, Regional Financial Effectiveness Ratios, Regional Financial Efficiency Ratios and General Allocation Funds have no influence on the Allocation of Capital Expenditures.

Novianto Indratno (2016), this study studies the Effect of Financial Ratios on Allocation of Capital Expenditures to Districts / Cities in Central Java Province. It can be concluded that the Regional Independence 
Ratio and Efficiency Ratio affect the Allocation of Capital Expenditures, while the Effectiveness Ratio and Regional Dependence do not affect the Allocation of Capital Expenditures.

Saragih (2018), conducted a study on the Effect of Regional Financial Independence Ratios, Effectiveness of Regional Original Revenue Ratios and Regional Financial Efficiency Ratios on District / City Government Capital Expenditures in North Sumatra Province 2014-2016. It can be concluded that the Regional Financial Independence Ratio has a significant negative effect on the Capital Expenditures while the Effectiveness of the Regional Original Income (PAD) and the Influenced Financial Efficiency Ratio are significantly positive.

\section{LOGICAL FRAMEWORK}

Regional Financial Independence influences Regional Capital Expenditure

One effort to maximize the use of capital expenditure is the existence of fiscal decentralization that provides opportunities for regions to build independence in obtaining funding. The realization of capital expenditure itself can be realized by using funds obtained by the regional government. The level of financial independence of the region is one of them is through local revenue (PAD). Independent local governments can certainly be seen from the extent to which capital expenditure can be maximized for the welfare of the community.

According to Dihan Lucky (2013), financial performance, one of which is regional financial independence has a positive but not significant effect on the realization of capital expenditure. Based on the theoretical and research foundation above, the first hypothesis can be formulated:

H1: Regional Independence influences Regional Capital Expenditures

Regional Financial Efficiency Affects Regional Capital Expenditures

Regional financial efficiency can be measured by dividing the realization of regional expenditure with the realization of regional revenues. This aims to see how far the efficiency of local governments in using their regional income. The higher the ratio obtained, the more wasteful it can be said the use of funds by the local government. Of course we must compare this efficiency value with the realization of capital expenditure. The government stipulates that at least capital expenditure must be at $30 \%$ of regional expenditure. And directly the regional financial efficiency is directly related to the allocation and realization of capital expenditure.

According to Dihan Lucky (2013), financial performance, one of which is regional financial efficiency, has a positive but not significant effect on the realization of capital expenditure. Based on the theoretical and research foundation above, the second hypothesis can be formulated:

H2: Regional Financial Efficiency influences Regional Capital Expenditures

Effectiveness of Regional Original Revenue affects Regional Capital Expenditures

the effectiveness of PAD realization can be calculated by dividing the realization of PAD with the PAD budget. This aims to see whether the regional government can realize PAD in accordance with the budgeted or not. The greater the ratio, the better the local government in maximizing the potential of the region it has. This has a relationship with the independence of the local government. The higher realization of local revenue can enable the realization of capital expenditure is also high, because the funding source for capital expenditure comes from local revenue.

H3: Effectiveness of Regional Original Revenue has an effect on Regional Capital Expenditures

Based on the previous descriptions, it can be used the model (chart) of the sub-structure of the research influence between research variables. As stated in figure 2.

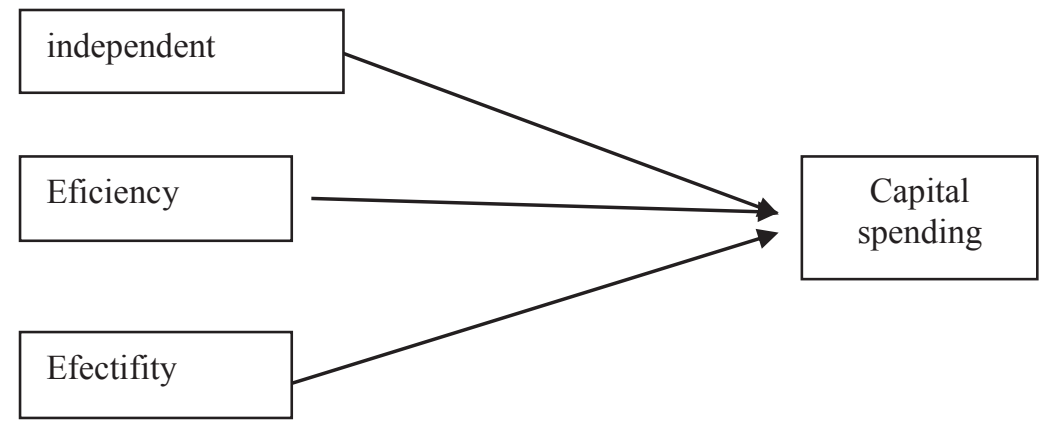

Figure 2. Logical framework

\section{RESEARCH METHODS}

Research design

The research method used in this study is causality research which aims to examine the influence of Regional Financial Independence, Regional Financial efficiency and Effectiveness of PAD on Capital Expenditures. The population and sample of this study were 33 provinces in Indonesia. The reason for choosing this sample is that 
the Province covers the City and Regency areas and has varying economic characteristics. The year of data used in this study is 2013-2017. The technique used to obtain a representative sample was purposive sampling, by removing incomplete samples because they could inhibit data analysis. The data used in this study is secondary data. Secondary data obtained from the Central Statistics Agency, as well as the Directorate General of Balance of the Ministry of Finance of the Republic of Indonesia. In the website www.bps.go.id and www.djpk.depkeu.go.id.

Data collection and measurement

The stages in the study are starting with:

a. Data collection in this study uses the library method, namely research conducted by studying the literature that is relevant to the problem and retrieving data from the Central Bureau of Statistics, as well as the Supreme Audit Board of the Republic of Indonesia.

b. Measurement of research variables by doing calculations:

1, Independent Variables consist of: Regional Financial Independence, Regional Financial Efficiency and

Effectiveness of Regional Original Income. Measurement scale used ratio scale.

2. Dependent Variables are Regional Capital Expenditures, measurement scale used ratio scale.

Definition of Operationalization

1. Regional Capital Expenditures,

Capital Expenditure is the budget for APBD expenditures used for expenditures carried out in the context of purchasing / procurement or construction of fixed assets that have benefits of more than 12 months.

2. Regional Financial Independence,

Regional Financial Independence is used to measure the government's dependence on external funds. The higher the regional independence ratio, the lower the level of regional reliance on external assistance and vice versa.

2. Regional Financial Efficiency,

Regional Financial Efficiency is used to measure the use of regional expenditure on regional income, the greater the ratio, the efficiency level is not good.

3. Effectiveness of Local Revenue

The effectiveness of Regional Original Income is used to measure the ability of regions to explore sources of income and maximize the potential of income to mobilize government activities.

\section{DATA ANALYSIS}

Descriptive Analysis

Based on the following table 5, it can be explained in full the variables observed, as follows.

Table 5. Descriptive analysis

\begin{tabular}{|l|r|r|r|r|}
\hline \multicolumn{1}{|c|}{ Variable } & Mean & \multicolumn{1}{c|}{ Standard Deviation } & \multicolumn{1}{c|}{ Minimum } & \multicolumn{1}{c|}{ Maximum } \\
\hline KKD &, 17878 &, 132760 &, 033 &, 762 \\
\hline EKD & 1,00689 &, 554802 &, 322 & 7,844 \\
\hline EK & 1,14166 &, 283062 &, 653 & 2,794 \\
\hline BM &, 23598 &, 052121 &, 125 &, 465 \\
\hline
\end{tabular}

Sources: data SPSS

From table 5. It can be seen that the average Regional Financial Independence of 33 provinces in Indonesia from 2013-2017 amounted to, 17878. This Regional Financial Independence has risen to its highest point of 762 in the DKI Jakarta province in 2015, and has decreased to the lowest point occurring in Central Sulawesi Province in 2017 reaching the level of 033 . With a deviation of, 132760 from the average.

Regional Financial Efficiency 33 provinces in Indonesia from 2013-2017 had an average of 1,00689. Regional Financial Efficiency has increased with the highest point of 7,844 in DI Yogyakarta Province in 2017, and has decreased to the lowest point in Central Sulawesi Province reaching the level of 322 in 2017. With a deviation of 554802 from the average. Effectiveness of Local Revenue 33 provinces in Indonesia from 20132017 have an average of 1.14166. Effectiveness of Regional Original Revenues has increased with the highest point of 2.794 in Prov. DKI Jakarta in 2017, and has declined to the lowest point in Central Sulawesi Province reaching the level of 653 in 2017 . With a deviation of, 283062 from the average.

The capital expenditure of 33 provinces in Indonesia from 2013-2017 has an average of, 23598. Capital expenditure has increased with the highest point of 465 in Prov. West Sulawesi in 2017, and has decreased to the lowest point in the Central Java province reaching the level of 125 in 2017 . With a deviation of, 052121 from the average.

Analysis of Multiple Linear Regression

To do multiple linear regression analysis, the steps of analysis are carried out as follows: 
Normality test

The normality test was carried out by the analysis of one-sample Kolmogorov-Smirnov. Decision making to determine the research variable data is normally distributed or not if the value is important. Sig ( 2 tailed) $>0.05$, then the data is normally distributed; and when the value of the Assumption. Sig ( 2 tailed $)<0.05$, then the data is not normally distributed.

The significance value of $\mathrm{K}-\mathrm{S}$ is still far below $\alpha=0.05$. This means that all variables are not normally distributed. Data that is not normally distributed can be outsourced to be normal. After dividing, the significance value of K-S is above $\alpha=0.05$, meaning that all variables are normally distributed. Regression analysis can be continued.

Table 6. (One-Sample Kolmogorov-Smirnov)

\begin{tabular}{|c|c|c|c|}
\hline & & $\begin{array}{l}\text { Unstandardized Residual } \\
\text { (sblm outlier) }\end{array}$ & $\begin{array}{l}\text { Unstandardized Residual } \\
\text { (stlh outlier) }\end{array}$ \\
\hline $\mathrm{N}$ & & 165 & 150 \\
\hline Normal Parameterca,b & Mean &, 0000000 &, 0000000 \\
\hline Normal Parameters ${ }^{a, 0}$ & Std. Deviation & ,04989708 &, 04443686 \\
\hline & Absolute &, 118 & ,092 \\
\hline Most Extreme Differences & Positive & 118 & ,092 \\
\hline & Negative &,- 056 &,- 039 \\
\hline Kolmogorov-Smirnov Z & & 1,510 & 1,124 \\
\hline Assumption. Sig. (2-tailed) & & 021 &, 160 \\
\hline
\end{tabular}

Source : secondary

Classic assumption test

Multicollinearity Test

Multicollinearity test seen from tolerance value and variance inflation factor (VIF). The results of the multicollinearity test of this study are shown by table 3 . The calculation results of the Tolerance value also show that there is no independent variable that has a Tolerance value of less than 0.10 which means there is no correlation between independent variables whose values are more than 0.95 . The VIF calculation results also show the same thing there is no one independent variable that has a VIF value of more than 10 . So it can be concluded that there is no multicollinearity between independent variables in the regression model.

Table 7. Multicolinearity

\begin{tabular}{|l|r|r|}
\hline & Tolerance & \multicolumn{1}{|l|}{ VIF } \\
\hline KKD & 0.976 & 1.025 \\
\hline EKD & 0.964 & 1.037 \\
\hline EK & 0.979 & 1.021 \\
\hline
\end{tabular}

Source: data

Heteroscedasticity Test

The examination of the symptoms of heteroscedasticity is to look at the scatter diagram pattern. If there are scattered diagrams forming certain patterns that are regular then the regression experiences a heteroscedasticity disorder. If the scatter diagram does not form a pattern or is random, the regression does not experience a heteroscedasticity disorder. The scatter diagram of this study did not form a regular pattern, so it can be concluded that heteroscedasticity does not occur in the regression model, and it is feasible to predict it. 
Scatterplot

Dependent Variable: BM



Source: secondary data processed

Autocorrelation Test

Figure 3. Scatter plot of Heteroscedasticity testing

The autocorrelation test aims to test whether in the linear regression model there is a correlation between interfering errors in period $t$ with period $t-1$ disturbing errors. One way to detect this is the Durbin-Watson test. From the results of the analysis it can be seen that the D-W value generated from the autocorrelation test is 0.802 where the Durbin-Watson value lies between -2 and 2 . Then $-2<0.802<2$, it can be concluded that there is no autocorrelation in the regression used.

Table 8. Regression analysis

\begin{tabular}{|c|c|c|c|c|}
\hline & $\mathbf{B}$ & Std. Error & $\mathbf{t}$ & Sig. \\
\hline (Constant) & 0.256 & 0.037 & 6.910 & 0.000 \\
\hline KKD & -0.109 & 0.029 & -3.797 & 0.000 \\
\hline EKD & 0.012 & 0.029 & 0.418 & 0.677 \\
\hline EK & -0.014 & 0.019 & -0.748 & 0.456 \\
\hline Dependent Variable & \multicolumn{4}{|c|}{ LBELANJA MODAL } \\
\hline F value & \multicolumn{4}{|c|}{4.901} \\
\hline Sig F & \multicolumn{4}{|l|}{0.003} \\
\hline Durbin Watson & \multicolumn{4}{|l|}{0,802} \\
\hline R Square & \multicolumn{4}{|l|}{0.091} \\
\hline Adjusted R Square & \multicolumn{4}{|l|}{0.073} \\
\hline
\end{tabular}

Sources: data

Coefficient of Determination (R2)

The coefficient of determination (R2) measures how far the model's ability to explain the variation of the dependent variable. If there is only one independent variable, R2 is used. But if there are two or more independent variables, then adjusted R2. Adjusted R2 values can go up or down if one independent variable is added to the model. In table 8 above, it can be seen that the adjusted value of R2 is 0.073 , this means that $0.73 \%$ of the variation in capital expenditure can be explained by variations of the three independent variables (KKD, $\mathrm{EKD}$, and EK). While the remaining $99.27 \%(100 \%-0.73 \%)$ is explained by other reasons outside the model.

Hypothesis testing

Simultaneous Significance Test (Test Statistic F) The F statistical test is to show whether all the independent variables referred to in the model have a joint effect on the dependent variable. By comparing probabilities (in the Anova table written Sig) with the actual level ( 0.05 or 0.01$)$. If the probability is $>0.05$, the model is rejected. If the probability is $<0.05$ then the model is accepted. Can be seen in table 8 , the value of $\mathrm{F}$ is 4,901 with 
probability 0,003 . Because the probability is far smaller than 0.01 , the regression model can be used to predict Capital Expenditures. Or it can be said that KKD, EKD, and EK, together have an effect on Capital Expenditure, and the form of linear regression equation is correct.

Individual Parameter Significance Test (Test Statistic t)

The $t$ statistical test shows how far the influence of one explanatory variable / independent individually in explaining the variation of the dependent variable. Whether the independent variables have a significant or not effect, a decision can be made for the hypothesis test, as follows:

Ho $=$ each independent variable has no significant effect on the dependent variable.

$\mathrm{Ha}=$ each independent variable has a significant effect on the dependent variable.

Decision makers can be done by looking at the probability, that is if the probability is $>0.01$, or 0.05 or 0.10 then the alternative hypothesis is rejected, if the probability is $<0.01$, or 0.05 or 0.10 then the alternative hypothesis is accepted.

From the results of calculations contained in table 8 , of the three independent variables included in the regression model, KKD has a significant effect on Capital Expenditures with the direction of the negative relationship EKD and EK have no effect on capital expenditure. This is seen from the probability of significance for the KKD of 0,000, EKD of 0.677, and EK 0.456. Thus it can be concluded that KKD has a significant effect on Capital Expenditures with a negative relationship direction, at alpha 1\% of Capital Expenditures. While EKD and EK have no effect on capital expenditure.

Regression Equation

From the results of the regression analysis calculations as listed in table 4.5 , the regression equation formed is as follows:

Capital Expenditure $=0.256-0.109 \mathrm{KKD}+0.012 \mathrm{EKD}-0.014 \mathrm{EK}+\mathrm{e}$

From the regression equation, it can be interpreted that:

1. The constant of 0.256 states that if the independent variable (KKD, EKD, and EK) is considered constant, then the average Capital Expenditures is $0.256 \%$.

2. KKD regression coefficient of -0.109 states that every $10 \%$ increase in KKD will reduce Capital Expenditures by $1.09 \%$.

3. EKD regression coefficient of 0.012 states that every $10 \%$ increase in EKD will increase Capital Expenditures by $0.12 \%$.

4. EK regression coefficient of - 0.014 states that every $10 \%$ increase in EK will reduce Capital Expenditures by $0.14 \%$

\section{Discussion}

From the results of this study it was found that Regional Financial Independence had a negative and significant effect on capital expenditure, while Regional Financial Efficiency and Effectiveness of Regional Original Revenues did not affect Capital Expenditures.

The results of this study indicate that Regional Financial Independence has a negative and significant effect on Capital Expenditures. This finding can be indicates that the higher the regional financial independence, the lower capital expenditures made by regional governments, this is estimated because more funds are allocated to meet personnel expenditure needs and operational expenditure, so capital expenditure for public services is relatively small. This research strengthens Saragih's research (2018), but it contradicts the research of Vella Kurniasih (2014) who found that regional financial independence did not affect capital expenditure.

Regional financial efficiency does not affect capital expenditure. In this study sample shows regional financial inefficiency, which is caused by overlapping funding in an activity that is not in accordance with budget implementation. This can be seen, the number of public services as they are, is not in accordance with the actual public needs. This research is in line with the research of Vella Kurniasih (2014) but it is different from the research of Novianto (2016) which found that regional financial efficiency has an effect on capital expenditure.

The effectiveness of local revenue does not affect capital expenditure. This condition occurs because the regional government cannot realize the planned PAD in accordance with the targets set, consequently the demands and needs of the community tend to be ignored so that the allocation of capital expenditure is not realized effectively, and this can hamper development in improving public service facilities. This research is in line with the research of Vella Kurniasih (2014), but it contradicts the research of Saragih (2018), which found that the ratio of effectiveness of local revenue has a positive significant effect on capital expenditure.

\section{CONCLUSIONS AND RECOMMENDATIONS}


Effectiveness of Regional Original Income on Capital Expenditures, from 33 Provinces in Indonesia. This study obtained results that: Regional Financial Independence has a negative and significant effect on moderate Capital Expenditures Regional Financial Efficiency and Effectiveness of Regional Original Income does not affect Capital Expenditures.

\section{Suggestion}

Taking into account the conclusions of this study, it can be suggested that: Local governments in Indonesia can better allocate capital expenditure in order to improve the welfare of the community in accordance with the principle of regional autonomy. Besides the Regional Government needs to carefully calculate the costs incurred for funding activities so that there is no overlap that causes waste, and the Regional Government can increase the effectiveness ratio of PAD, so that it is expected that Capital Expenditure can be allocated better.

\section{REFERENCES}

Abdul Halim. 2008, Akuntansi Keuangan Daerah, Edisi3. Jakarta, Salemba Empat

Adha, R. B. (2016). Pengaruh Belanja Daerah dan Kinerja Keuangan Daerah Terhadap Kemiskinan (Studi Kasus Pada Kabupaten/Kota Di Provinsi Lampung. Lampung: Universitas Lampung .

Ani, N. N. (2014). Pengaruh Kinerja Keuangan Daerah Pada Pertumbuhan Ekonomi, Pengangguran dan Kemiskinan Kabupaten dan Kota. Bali: Universitas Udayana.

Ardhana, A. A., Masinambow, V. A., \& Wauran, P. (2016). Pengaruh Belanja Modal dan Investasi Swasta Terhadap Kesejahteraan Masyarakat Melalui Kesempatan Kerja di Provinsi Sulawesi Utara Periode 2003 - 2013. Manado: Universitas Sam Ratulangi.

Ardhini. (2011). Pengaruh Rasio Keuangan Daerah terhadap Belanja Modal untuk Pelayanan Publik Dalam Perspektif Teori Keagenan (Studi Pada Kabupaten dan Kota di Jawa Tengah). Jurnal Universitas Diponegoro, Semarang. Online 26 November 2013.

Ashworth, R., G. Boyne., dan R. Delbridge. (2009). Escape from the Iron Cage? Organizational Change and Isomorphic Pressures in the Public Sector. Journal of Public Administration Research and Theory

Assyurriani, Raja. 2015. “Pengaruh Rasio tingkat Kemandirian Daerah, Rasio Efektivitas, Rasio Aktivitas, Rasio Pertumbuhan secara bersamaan terhadap Belanja Modal di Pemerintahan Kabupaten dan Pemerintahan Kota di Kepulauan Riau Tahun 2010-2013". Jurnal, Universitas Maritim Raja Ali Haji Tanjungpinang.

Aula Ahmad. 2013. Analisis Rasio Keuangan Darah dalam Mempengaruhi Belanja Modal Publik Bagi Pertumbuhan Ekonomi”. Jurnal, Universitas Negeri Yogyakarta.

Cahya, B. T. (2014). Pengaruh Kinerja Keuangan Terhadap Pertumbuhan Ekonmi dan Kemiskinan. Surakarta: Universitas Muhammadiyah Surakarta.

Dacin, M. T. (1997). Isomorphism in Context: The Power and Prescription of Institutional Norms. The Academy of Management Journal.

DiMaggio,P. J. dan W. W. Powell. (1983). The Iron Cage Revisited: Institutional Isomorphism and Collective Rationality in Organizational Fields. American Sociological Review

Direktorat Jenderal Perimbangan Keuangan. Visualisasi Data APBD - Tabel Agregat. Diambil kembali dari: http://www.djpk.kemenkeu.go.id

Dwirandra. (2016). Kemampuan Pertumbuhan Ekonomi Memoderasi Pengaruh Kinerja Keuangan Terhadap Tingkat Kemiskinan.. Bali: Universitas Udayana.

Emzir. (2012). Metodologi Penelitian Pendidikan Kuantitatif dan Kualitatif.

Fakhry, S. M. (2017). Pengaruh Kinerja Keuangan Terhadap Alokasi Belanja Modal Pemerintah Kabupaten dan Kota di Provinsi Lampung. Lampung : Universitas Lampung

Frumkin, P. Dan J. Galaskiewicz. (2004). Instutional Isomorphism and Public Sector Organizations. Jurnal of Public Administration Research and Theory.

Halim, A. dan Kusufi, M. S. (2013). Akuntansi Sektor Publik: Akuntansi Keuangan Daerah. Jakarta: Salemba Empat.

Halim, A. (2016). Manajemen Keuangan Sektor Publik. Jakarta: Salemba Empat

Hidayat, M. F. (2013). Analisis Pengaruh Kinerja Keuangan Daerah terhadap Alokasi Belanja Modal (Studi Pada Kabupaten dan Kota di Jawa Timur). Malang: Universitas Brawijaya.

Imam Ghozali. 2013. Aplikasi Analisis Multivariate dengan Program SPSS. Edisi ketujuh. Semarang. Badan Penerbit Universitas Diponegoro.

Indratno, Novianto. 2016. Pengaruh Rasio Kemandirian Daerah, Rasio Efektivitas, Rasio Efisiensi dan Rasio Ketergantungan Daerah terhadap Alokasi Belanja Modal pada Kabupaten/Kota di Propinsi Jawa Tengah tahun 2012-2014”. Jurnal Universitas Muhammadiyah Surakarta.

Lucky, D. (2013). Analysis of The Effect of Regional Financial Performance to Economic Growth and Poverty Through Capital Expenditure (Case study of 38 Regencies / Cities in East Java Province). Malang: 
Universitas Brawijaya.

Mafizatun Nurhayati (2014), Pengaruh Dana Perimbangan Daerah terhadap Pertumbuhan Ekonomi Daerah dan Kesejahteraan Masyarakat 33 Provinsi di Indonesia, Jakarta, Universitas Mercu Buana.

Mahmudi. (2016). Analisis Laporan Keuangan Pemerintah Daerah. Yogyakarta: UPP STIM YKPN

Meyer, J. dan Rowan. B. (1977). Institutionalized Organizations Formal Structure as Myth and Ceremony. The American Journal of Sociology.

Nana, N. L. (2014). Pengaruh Kinerja Keuangan Daerah Pada Pertumbuhan Ekonomi, Pengangguran Dan Kemiskinan Kabupaten Dan Kota. Bali : Universitas Udayana

Novianto (2016). Pengaruh Rasio Keuangan terhadap Alokasi Belanja Modal Kabupaten/Kota di Provinsi Jawa Tengah. Surakarta : Universitas Muhammadiyah Surakarta.

Okulegu, E. B. (2013). Government Spendings and Poverty Reduction in Nigerian' Economic. Abakaliki: Ebonyi State University.

Olagbaju, O. I. (2015). Effect of Government Capital Expenditure on Public Welfare Output in Nigeria. Osun State: Macrothink Institute.

Omari, L. V., \& Muturi, W. (2016). The Effect of Government Sectoral Expenditure on Poverty Level. Nairobi: Kenya.

Osundina, C., Ebere, Chidinma, \& Osundina, O. (2014). Disaggregated Government Spending on Infrastructure and Poverty. Ogun State: Babcock University.

Praza, E. I. (2016). Analisis Pengaruh Kinerja Keuangan Terhadap alokasi Belanja Modal di Provinsi Jambi. Jambi : Universitas Jambi

Pramit, R. (2015). Manajemen Keuangan Daerah. Jakarta: Salemba Empat

Putu, G. (2016). Analisa Laporan Keuangan Sektor Publik. Bandung: Pustaka Setia.

Republik Indonesia. Nota Keuangan Beserta Rancangan Pendapatan Dan Belanja Negara Tahun Anggaran. Jakarta : Sekretariat Negara.

Republik Indonesia. (2015). Peraturan Presiden Nomor 5 Tahun 2015 tentang RPJMN Tahun 2015 - 2019. Jakarta: Sekretaris Kabinet.

Republik Indonesia. (2015). Peraturan Menteri Keuangan Nomor 127/PMK.02/2015 tentang Klasifikasi Anggaran. Jakarta: Kementerian Keuangan

Republik Indonesia. (2014). Undang - undang Nomor 33 Tahun 2014 tentang Perimbangan Keuangan Antara Pemerintah Pusat dan Pemerintahan Daerah. Jakarta: Sekretariat Negara.

Republik Indonesia. (2014). Undang - undang Nomor 32 Tahun 2014 tentang Pemerintahan Daerah. Jakarta: Sekretariat Negara.

Republik Indonesia. (2010). Peraturan Presiden Nomor 5 Tahun 2010 tentang RPJMN Tahun 2010 - 2014. Jakarta: Sekretaris Kabinet.

Republik Indonesia. (2006). Peraturan Menteri Dalam Negeri No. 13 Tahun 2006 tentang Pedoman Pengelolaan Keuangan Daerah. Jakarta: Kementerian Dalam Negeri.

Republik Indonesia. (2005). Peraturan Pemerintah Nomor 24 tahun 2005 tentang Standar Akuntansi Pemerintah Pernyataan Nomor 2. Jakarta: Sekretariat Negara. BIBLIOGRAPHY $\backslash 1033$

Republik Indonesia. (2005). Peraturan Presiden Nomor 12 Tahun 2005 tentang Program Langsung Tunai. Jakarta: Sekretaris Kabinet.

Republik Indonesia. (2004). Undang - undang Nomor 24 Tahun 2004 tentang Lembaga Penjamin Simpanan. Jakarta: Sekretariat Negara.

Republik Indonesia. (2004). Undang - undang Nomor 15 Tahun 2004 tentang Pemeriksaan Pengelolaan dan Tanggungjawab Keuangan Negara. Jakarta: Sekretariat Negara.

Republik Indonesia. (2004). Undang - undang Nomor 1 Tahun 2004 tentang Perbendaharaan Negara. Jakarta: Sekretariat Negara.

Republik Indonesia. (2003). Undang - undang Nomor 17 Tahun 2003 tentang Keuangan Negara. Jakarta: Sekretariat Negara.

Rosadi, A. I. (2017). Pengaruh Kinerja Keuangan, Dana Alokasi Umum dan SiLPA pada Alokasi Belanja Modal. Bali: Universitas Udayana.

Saragih, Anita G. (2018). Pengaruh Rasio Kemandirian Keuangan Daerah, Rasio Efektivitas Pendapatan Asli Daerah dan Rasio Efisiensi Keuangan Daerah terhadap Belanja Modal Pemerintah Kabupaten/Kota di Provinsi Sumatera Utara tahun 2014-2016, Sumatera Utara, Universitas Sumatera Utara.

Scott, W. R. (1987). The Adolescence of Institutional Theory. Administrative Science Quarterly

Sedarmayanti. (2014). Manajemen Sumber Daya Manusia Reformasi Birokrasi dan Manajemen Pegawai Negeri Sipil. Bandung: Refika Aditama

Setiawina, I. K. A. N. D. (2015). Pengaruh Kinerja Keuangan pada Alokasi Belanja Modal Dan Pertumbuhan Ekonomi Pemerintah Kabupaten / Kota Se-Provinsi Bali Tahun 2006 S.D 2013. Bali: Universitas Udayana

Sugiyono. (2013). Metode Penelitian Bisnis. Bandung: Alfabeta. 
Sularso, Havid dan Yanuar E, Restianto. 2011. "Pengaruh Kinerja Keuangan terhadap Alokasi Belanja Modal dan Pertumbuhan Ekonomi Kabupaten/Kota di Jawa Tengah.” Jurnal Riset Akuntansi, Vol 1, No.2, Agustus 2011.

Suryabrata, S. (2014). Metodologi Penelitian. Jakarta : PT Raja Grafindo Persada.

Suyanto, B. (2013), Anatomi Kemiskinan Dan Strategi Penanganannya, Penerbit Intrans Publishing, Malang

Vella Kurniasih, (2014). Pengaruh Rasio Keuangan Daerah, Pendapatan Asli Daerah (PAD),dan Dana Alokasi Umum (DAU) terhadap Alokasi Belanja Modal pada Kabupaten/Kota provinsi Riau. Jurnal online Vol 1, No.1 2014.

World Bank; International Monetatry Fund. (2016). Global Monitoring Report 2015/2016 : Development Goals in an Era of Demographic Change. Washington DC: World Bank.

Yulia Yustikasari (2018), Pengaruh Kemandirian Daerah, Ketergantungan Daerah, Efektivitas Realisasi Pendapatan Asli Daerah dan Belanja Modal terhadap Akuntabilitas Pelaporan Keuangan Daerah pada Pemerintah Daerah tingkat Provinsi di Indonesia periode 2013-2015. Jakarta, Universitas Mercu Buana. 